\title{
Correction to: Psi-PIV: a novel framework to study unsteady microfluidic flows
}

\author{
Ankur Kislaya $^{1}{ }^{\mathbb{D}} \cdot$ Antaran Deka $^{1} \cdot$ Peter Veenstra $^{2} \cdot$ Daniel S. W. Tam $^{1} \cdot$ Jerry Westerweel $^{1}$
}

Published online: 18 February 2020

(c) The Author(s) 2020

\section{Correction to: Experiments in Fluids (2020) 61:20 https://doi.org/10.1007/s00348-019-2855-6}

The original version of this article contained a mistake. The symbol $\Psi$ in the article title was inadvertently replaced with text. The correct article title is: Psi-PIV: a novel framework to study unsteady microfluidic flow.

This erratum corrects the mistake and original article is updated.

Open Access This article is licensed under a Creative Commons Attribution 4.0 International License, which permits use, sharing, adaptation, distribution and reproduction in any medium or format, as long as you give appropriate credit to the original author(s) and the source, provide a link to the Creative Commons licence, and indicate if changes were made. The images or other third party material in this article are included in the article's Creative Commons licence, unless indicated otherwise in a credit line to the material. If material is not included in the article's Creative Commons licence and your intended use is not permitted by statutory regulation or exceeds the permitted use, you will need to obtain permission directly from the copyright holder. To view a copy of this licence, visit http://creativecommons.org/licenses/by/4.0/.

Publisher's Note Springer Nature remains neutral with regard to jurisdictional claims in published maps and institutional affiliations.

The original article can be found online at https://doi.org/10.1007/ s00348-019-2855-6.

Ankur Kislaya

a.kislaya@tudelft.nl

1 Laboratory for Aero and Hydrodynamics, Delft University of Technology, Delft, The Netherlands

2 Shell Global Solutions International B.V., The Hague, The Netherlands 